\title{
External Ear Carcinoma
}

National Cancer Institute

\section{Source}

National Cancer Institute. External Ear Carcinoma. NCI Thesaurus. Code C6081.

A carcinoma that arises from the external ear. This category includes squamous cell carcinoma, basal cell carcinoma, and ceruminous adenocarcinoma. 